\title{
STUDY ON THE ESTABLISHMENT OF A MAINTENANCE MODE FOR A BIM-BASED LANDSCAPE PROJECT
}

\author{
YI-JAO CHEN, HUI-YI KUO \& CHI-JEN CHEN \\ Department of Architecture, National University of Kaohsiung, Taiwan
}

\begin{abstract}
The maintenance of landscape construction projects exhibits several distinct features including long life cycles, high costs, and a variety of influencing factors. Landscape information modeling (LIM), developed based on the concept of building information modeling (BIM), has been applied in landscape design with several preliminary achievements. However, the current database structure associated with a landscape information model does not include any information required for the maintenance of a landscape project. Therefore, this study focused on the maintenance and management of landscape projects. Specifically, we first presented a detailed discussion on the information requirement for the maintenance and management of landscape projects. Based on these requirements, a building information model for describing the maintenance information is established. Finally, a BIM-based landscape maintenance and management system is developed and validated with a practical case study. The case study reveals high integrity, mobility, and effectiveness of the collected information for use in landscape maintenance. In addition, instantaneous visualization of the information is also demonstrated in the study, which provides great convenience for practical maintenance work.
\end{abstract}

Keywords: landscape projects, BIM, facility maintenance and management.

\section{INTRODUCTION}

When considering the entire life cycle of a particular project, the operation and maintenance can play an even more important role than its design and construction. Traditional approaches for maintaining and managing a facility still primarily rely on paper-based documents such as drawings, facility information documents, and warranty documents. However, after completion of construction, when such an engineering project becomes increasingly larger in scale and more complex, the content conveyed by these drawings can no longer satisfy the owner's operation and maintenance requirements of the facility [1], [2].

Among different types of maintenance works, the maintenance of a landscape project is particularly demanding owing to its long life cycle, high costs, and a variety of influencing factors. In addition, the different trees, shrubs, vines, grass, flowers, and aquatic plants grown in a landscape project require distinct growth environments. With these complex environmental factors, even the most professional landscape designer may fail to cover every aspect in the landscape design. In addition, considering that not every single frontline maintenance and management operator possesses adequate professional knowledge and skill, certain mistakes and malfunctions are expected during the maintenance and management process. While it is possible to improve the working efficiency using a facility maintenance and management system, whether the data associated with the complex facilities in the system can meet the information requirements of the maintenance operations is still a challenge by itself. Furthermore, an effective method for maintaining a landscape project is still lacking in most studies [3].

Recent studies have proposed the concept of landscape information modeling (LIM) as a natural extension of BIM to landscape engineering design [4], [5]. However, the application of BIM during the operation and maintenance stage of the facility has only been explored by limited preliminary studies [6]. Currently, it is still impossible to apply BIM to practical maintenance and management operations of a landscape facility. In addition, a feasible model 
for applying BIM to the maintenance of landscape project and the establishment of a relevant architecture are still lacking [3], [4]. This is primarily caused by two reasons. On one hand, current BIM platforms are mainly established targeting the requirements during the design and construction stages. On the other hand, the database structure of a building information model does not include necessary information required for performing landscape maintenance of projects. Therefore, the objective of this study is to first analyze the information requirement for maintenance and management practices of a BIM-based landscape project, then establish a landscape component standard attribute architecture that describes multiple maintenance and management information content, and finally develop a feasible BIM-based landscape maintenance and management model. The feasibility of the proposed model will be validated by a case study.

\section{INFORMATION REQUIREMENT FOR BIM-BASED LANDSCAPE MAINTENANCE PRACTICE}

The maintenance and management practices of plants in a landscape project can be classified into two categories including a routine maintenance and a failure maintenance. With this in consideration, the operation process and the information presentation method for both types of plant maintenance practices are proposed in this study. In plant maintenance work, the operator typically has to deal with a mixture of arbor trees and shrubs. Depending on the actual operation content, different mechanical equipment and labor power may be required for different types of plants. Therefore, a one-to-multiple information model is used for classification in this maintenance operation practice. In this study, maintenance work for trees, shrubs, and ground covers are all analyzed systematically. Fig. 1 shows the maintenance information relationship diagram using arbor trees as an example.

The plants encountered in the maintenance practices can be classified into arbor trees, shrubs, the ground cover, and the lawn. Maintenance operations include pruning, lawn work, drug spraying, stent fixation, among others. In order to obtain the attribute information requirements for maintenance operations of different plants, attribute data are first divided into the following fields in this study: plant growth factors, types of machinery, personnel requirements, and waste disposal. Next, each plant category is associated with a maintenance operation. The content of the attribute data is summarized according to the requirement of each type of maintenance operation, as shown in Table 1. Taking the maintenance of arbor trees for example, their primary maintenance work includes watering, fertilization, pest

\section{Plant types Maintenance work items Attribute information}

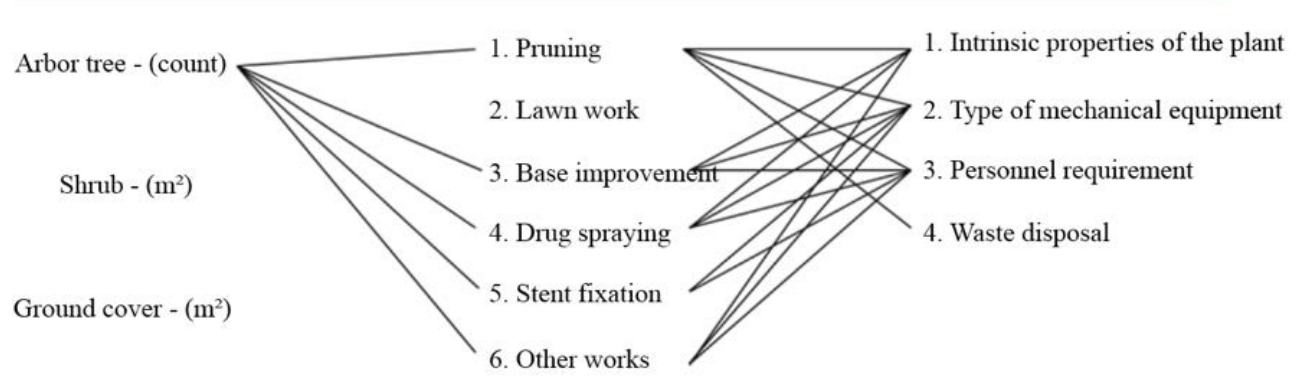

Figure 1: One-to-multiple information diagram for maintenance of arbor trees. 
Table 1: Plant maintenance/management work and participating personnel.

\begin{tabular}{|c|c|c|c|}
\hline Plant type & \multicolumn{2}{|c|}{$\begin{array}{l}\text { Maintenance/management } \\
\text { work content }\end{array}$} & $\begin{array}{l}\text { Personnel participating } \\
\text { in the maintenance }\end{array}$ \\
\hline \multirow{2}{*}{ Arbor tree } & \multirow{2}{*}{ Pruning } & Arbor tree pruning & \multirow{2}{*}{ Management unit } \\
\hline & & Shrub pruning & \\
\hline \multirow{2}{*}{ Shrub } & \multirow{2}{*}{ Lawn work } & Lawn trim & \multirow{2}{*}{ Inspection unit } \\
\hline & & Weed removal & \\
\hline \multirow{6}{*}{$\begin{array}{l}\text { Ground cover and } \\
\text { lawn }\end{array}$} & \multirow{3}{*}{$\begin{array}{l}\text { Drug } \\
\text { spraying }\end{array}$} & Fertilization & \multirow{3}{*}{ Maintenance unit } \\
\hline & & Pest control & \\
\hline & & Weed suppression & \\
\hline & $\begin{array}{l}\text { Stent } \\
\text { fixation }\end{array}$ & $\begin{array}{l}\text { Stent fixation and } \\
\text { adjustment }\end{array}$ & Design unit \\
\hline & \multirow{2}{*}{$\begin{array}{l}\text { Other } \\
\text { works }\end{array}$} & Watering & \multirow{2}{*}{ Construction unit } \\
\hline & & Replanting & \\
\hline
\end{tabular}

control, bracket support, and tree trimming. The attribute data required according to each of these items are classified into four groups including plant growth factors, types of machinery, personnel requirements, and waste disposal. Then, each work content will be related to different attributes. For example, the attribute information related to the watering of arbor trees are plant growth factors, types of machinery, and personnel requirements. Following this approach, we can analyze each planting object with its attribute content and obtain the corresponding attribute information. The attribute information associated with the maintenance work of other plants are summarized following the same procedure.

After analyzing the maintenance work items and their associated attribute information content, an information management model is further proposed in this study. As shown in Fig. 2, in traditional maintenance work, the planting location is determined by a field operator according to the planting configuration diagram. Therefore, the scope of maintenance and actual operations are scheduled and summarized after confirming the type and quantity of the plants. By establishing a cloud database of the information associated with plant maintenance and management work, the manager can now directly manage the database through the cloud. The maintenance operator can also record the work content and results in the cloud database immediately after finishing the maintenance work. In contrast, failure maintenance work is mostly required to handle emergency accidents. In a traditional operation flow work, the manager is first informed of the accident site and condition. Subsequently, maintenance operators are sent to the accident site together with the required mechanical equipment for handling the accident. After finishing the work, the operator will record the work and report it to the management units. In this type of workflow, a considerable amount of time is consumed on understanding the site condition. Therefore, herein, we propose to establish a cloud database for storing relevant information content. In case of an accident, the management and maintenance units can quickly familiarize themselves with the situation at the site through the database and allow for proper planning of the subsequent work. Furthermore, the resolution process and results of the accident can be recorded in the cloud database to enable the management unit to understand on-site conditions and relevant content in time. Fig. 3 shows the planning process. 


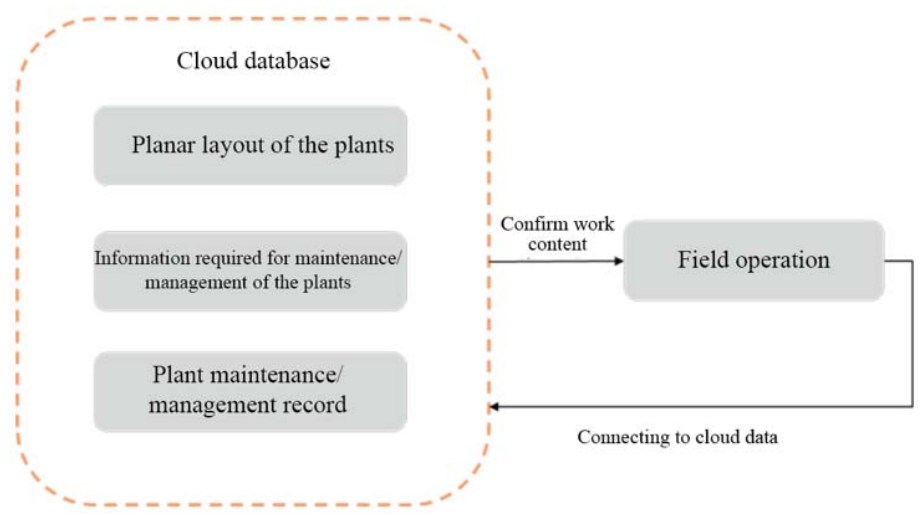

Figure 2: Work architecture of routine maintenance of plants.

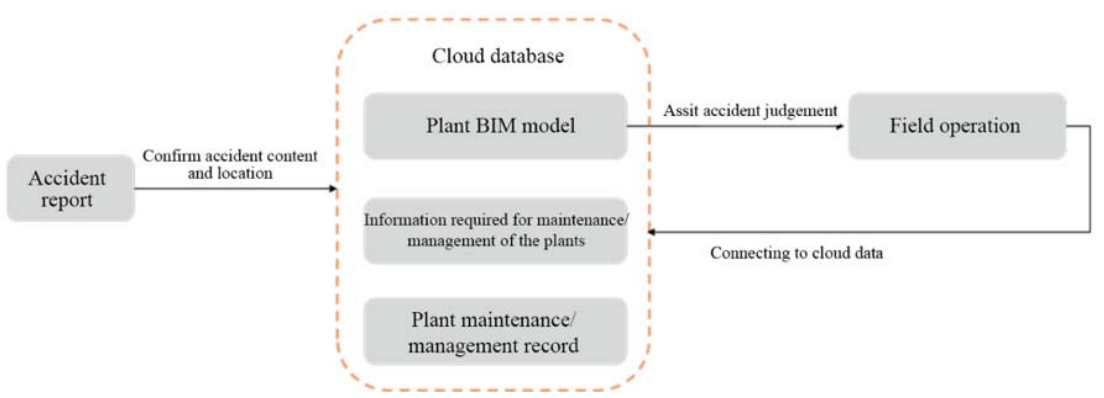

Figure 3: Work architecture for failure maintenance of plants.

\section{ATTRIBUTE ARCHITECTURE AND MODEL CONSTRUCTION OF BIM COMPONENTS FOR LANDSCAPE MAINTENANCE AND MANAGEMENT}

In this study, the landscape components in the BIM architecture are classified using the OmniClass Table. The objective is to analyze the information of component units effectively and organize these units for application. Based on our findings, plant components are classified using the OmniClass Table, as shown in Tables 2 and 3.

Table 2: Hierarchical classification of OmniClass.

\begin{tabular}{|c|c|c|c|c|c|}
\hline OmniClass code & First layer & Second layer & Third layer & Fourth layer & Fifth layer \\
\hline 23.40 .00 .00 & $\begin{array}{l}\text { Equipment } \\
\text { and } \\
\text { furniture }\end{array}$ & & & & \\
\hline 23.40 .05 .00 & & $\begin{array}{l}\text { Plants and } \\
\text { planting products }\end{array}$ & & & \\
\hline 23.40 .05 .17 & & & Outdoor planting & & \\
\hline 23.40 .05 .17 .11 & & & & Ground cover & \\
\hline 23.40 .05 .17 .14 & & & & Bulbous plant & \\
\hline 23.40 .05 .17 .17 & & & & Arbor tree & \\
\hline 23.40 .05 .17 .21 & & & & Coniferous trees & \\
\hline 23.40 .05 .17 .24 & & & & Deciduous tree & \\
\hline
\end{tabular}


Table 3: COBie information architecture for plant maintenance.

\begin{tabular}{|c|c|c|c|c|}
\hline \begin{tabular}{|l|} 
Major plant \\
maintenance \\
works
\end{tabular} & $\begin{array}{l}\text { Information } \\
\text { requirement }\end{array}$ & Plant characteristics & $\begin{array}{l}\text { Environment } \\
\text { information }\end{array}$ & $\begin{array}{l}\text { Comprehensive } \\
\text { information }\end{array}$ \\
\hline \multirow{3}{*}{ Pruning } & $\begin{array}{l}\text { BIM component } \\
\text { information : }\end{array}$ & $\begin{array}{l}\text { Plant growth period, type, } \\
\text { size, quantity, pruning }\end{array}$ & $\begin{array}{l}\text { Sunshine, planting } \\
\text { environment, season }\end{array}$ & $\begin{array}{l}\text { Model environment, } \\
\text { location }\end{array}$ \\
\hline & COBie parameter : & $\begin{array}{l}\text { Mechanical equipment and } \\
\text { manpower required for plant } \\
\text { trimming }\end{array}$ & & Frequency, cost \\
\hline & File: & $\begin{array}{l}\text { Bad branch pruning plan, } \\
\text { tree pruning plan, cross } \\
\text { maintenance plan }\end{array}$ & & $\begin{array}{l}\text { Planting component } \\
\text { location, name, } \\
\text { quantity }\end{array}$ \\
\hline \multirow{3}{*}{ Lawn work } & $\begin{array}{l}\text { BIM component } \\
\text { information : }\end{array}$ & & $\begin{array}{l}\text { Planting location, } \\
\text { season, soil } \\
\text { composition } \\
\end{array}$ & \\
\hline & COBie parameter : & & & \\
\hline & File: & & & \\
\hline \multirow{3}{*}{$\begin{array}{l}\text { Base } \\
\text { improvemen } \\
t\end{array}$} & $\begin{array}{l}\text { BIM component } \\
\text { information : }\end{array}$ & $\begin{array}{l}\text { Planting growth period, } \\
\text { type, specification, quantity, } \\
\text { fertilization period }\end{array}$ & Planting environment & Frequency, cost \\
\hline & COBie parameter : & $\begin{array}{l}\text { Fertilizer type, label, } \\
\text { quantity used, manpower, } \\
\text { cost }\end{array}$ & Fertilization area & $\begin{array}{l}\text { Planting component } \\
\text { location, name, } \\
\text { quantity }\end{array}$ \\
\hline & File: & & & \\
\hline \multirow{3}{*}{$\begin{array}{l}\text { Drug } \\
\text { spraying }\end{array}$} & $\begin{array}{l}\text { BIM component } \\
\text { information : }\end{array}$ & $\begin{array}{l}\text { Planting species, } \\
\text { specifications, quantity, pest } \\
\text { and disease season, control } \\
\text { season }\end{array}$ & $\begin{array}{l}\text { Planting environment, } \\
\text { season }\end{array}$ & Model environment \\
\hline & COBie parameter : & $\begin{array}{l}\text { Types of pests and diseases, } \\
\text { types of drugs, usage, }\end{array}$ & Control area & $\begin{array}{l}\text { Planting component } \\
\text { location, name, } \\
\text { quantity }\end{array}$ \\
\hline & File: & $\begin{array}{l}\text { Pesticide use plan, pest } \\
\text { control plan }\end{array}$ & & \\
\hline \multirow{3}{*}{$\begin{array}{l}\text { Stent } \\
\text { fixation }\end{array}$} & $\begin{array}{l}\text { BIM component } \\
\text { information : }\end{array}$ & $\begin{array}{l}\text { Arbor specifications, } \\
\text { location, connection } \\
\text { relationship }\end{array}$ & $\begin{array}{l}\text { Component name, } \\
\text { location, connection } \\
\text { relationship }\end{array}$ & $\begin{array}{l}\text { Component name, } \\
\text { location, connection } \\
\text { relationship }\end{array}$ \\
\hline & COBie parameter : & $\begin{array}{l}\text { Stent type, plant } \\
\text { specifications }\end{array}$ & & \\
\hline & File: & & & \\
\hline \multirow{3}{*}{ Other works } & $\begin{array}{l}\text { BIM component } \\
\text { information : }\end{array}$ & $\begin{array}{l}\text { Planting characteristics, } \\
\text { types, specifications, } \\
\text { quantities, water } \\
\text { requirements }\end{array}$ & $\begin{array}{l}\text { Planting environment, } \\
\text { season }\end{array}$ & $\begin{array}{l}\text { Model environment, } \\
\text { location }\end{array}$ \\
\hline & COBie parameter : & Water quantity, frequency & & \\
\hline & File : & & & \\
\hline
\end{tabular}

The first layer is equipment and furniture (i.e., the product category), the second layer is plants and planting products, the third layer is outdoor planting, and the fourth layer is the planting sequence. Such a sequence follows the order of ground cover, bulbous plants, shrubs, conifers, and deciduous trees. Therefore, the planting code of the planting components is determined using this classification, as shown in Table 2. The rest of the information is included and compiled in the form of component field expansion to make it consistent with the additional information in the specification. Based on the analysis results 
of the plant maintenance requirements, the maintenance works are further classified into the following categories according to their content: pruning, lawn work, base improvement, drug spraying, stent fixation, and other works. Furthermore, the information required for performing plant maintenance and management work is summarized in a COBie table architecture, as shown in Table 3.

After reviewing the COBie standard manual and determining the new information implemented in the table, the specifications related to the new information are further analyzed. Taking the planting component as an example, we first filtered out the new information added to the table by comparing the information requirements. The information that requires further analysis is shown in Table 4. Specifically, the planting characteristics, maintenance and management material, and the establishment of a relationship between different documents are all new information. Among them, the intrinsic characteristic of plants is categorized in the order of high, medium, and low to distinguish the operating frequency. In the maintenance management data fields, the medium growth period and the period suitable for fertilization are filled in terms of months to provide a reference for future activity planning. As there is too much content included in the maintenance and management operation table, this excess information is only presented as an attached link. This approach addresses the reading difficulty that arises when there is too much content in the data table.

Table 4: Maintenance information requirements and comparison of specifications.

\begin{tabular}{|c|c|c|}
\hline Classification & Information requirement & $\begin{array}{l}\text { Whether it exists in } \\
\text { the specification }\end{array}$ \\
\hline \multirow{11}{*}{$\begin{array}{l}\text { Intrinsic characteristics } \\
\text { of the plants }\end{array}$} & Plant name & Yes \\
\hline & Plant type & Yes \\
\hline & Location/specifications & Yes \\
\hline & Planting characteristics & No, must be added \\
\hline & Wind resistance & No, must be added \\
\hline & Drought resistance & No, must be added \\
\hline & Moisture resistance & No, must be added \\
\hline & Barren resistance & No, must be added \\
\hline & Heat resistance & No, must be added \\
\hline & Shade tolerance & No, must be added \\
\hline & Salinity tolerance & No, must be added \\
\hline \multirow{4}{*}{$\begin{array}{l}\text { Maintenance and } \\
\text { management information }\end{array}$} & Growth period & No, must be added \\
\hline & $\begin{array}{l}\text { Period suitable for } \\
\text { transplanting }\end{array}$ & No, must be added \\
\hline & Period suitable for trimming & No, must be added \\
\hline & Period suitable for fertilizing & No, must be added \\
\hline \multirow{6}{*}{$\begin{array}{l}\text { Maintenance and } \\
\text { management work form }\end{array}$} & $\begin{array}{l}\text { Plant maintenance and } \\
\text { management plan }\end{array}$ & No, must be added \\
\hline & $\begin{array}{l}\text { Arbor tree bad branch } \\
\text { pruning plan }\end{array}$ & No, must be added \\
\hline & Arbor tree pruning plan & No, must be added \\
\hline & Cross-dimensional plan & No, must be added \\
\hline & Pesticide use plan & No, must be added \\
\hline & Pest control plan & No, must be added \\
\hline
\end{tabular}


In this study, Autodesk Revit is used to develop the landscape components and establish the associated model. Based on previous results on the information requirement of BIM components, content must be written in the specifications after confirming the information of BIM components. The writing of information can be achieved in three ways: (1) information is generated automatically by the drawing components in Revit (e.g., length, pipe diameter); (2) COBie parameters are directly written in the Revit file; and (3) MS Excel forms are exported through the COBie Toolkit. Therefore, it is important to first inspect the method used for writing the information in order to mitigate any duplicate or missing information. Next, a case study is performed using the planting component as an example. The information content required for connecting the type is constructed using the "type nature" in Revit. The components are used to connect different content in the case study. Therefore, when constructing the data form, it is necessary to establish the information required by the specification in each mode. Certain information such as name, producer, and location can be established by the COBie Toolkit, while documents such as the maintenance manual are constructed in Excel and are exported using the COBie Toolkit. After confirming the completion of the required components and information modes, we then proceed to establish a building information model according to each mode and further complete the COBie information content. In addition, there is a significant lack of landscape components in current BIM software. The incompatibility of several planting components in the local environment also makes them not applicable to the planning of domestic landscape plants. Therefore, in this study, we constructed relevant BIM components based on common plants used in domestic landscape projects. Furthermore, self-developed BIM components were defined in terms of attribute expansion, as shown in Fig. 4.

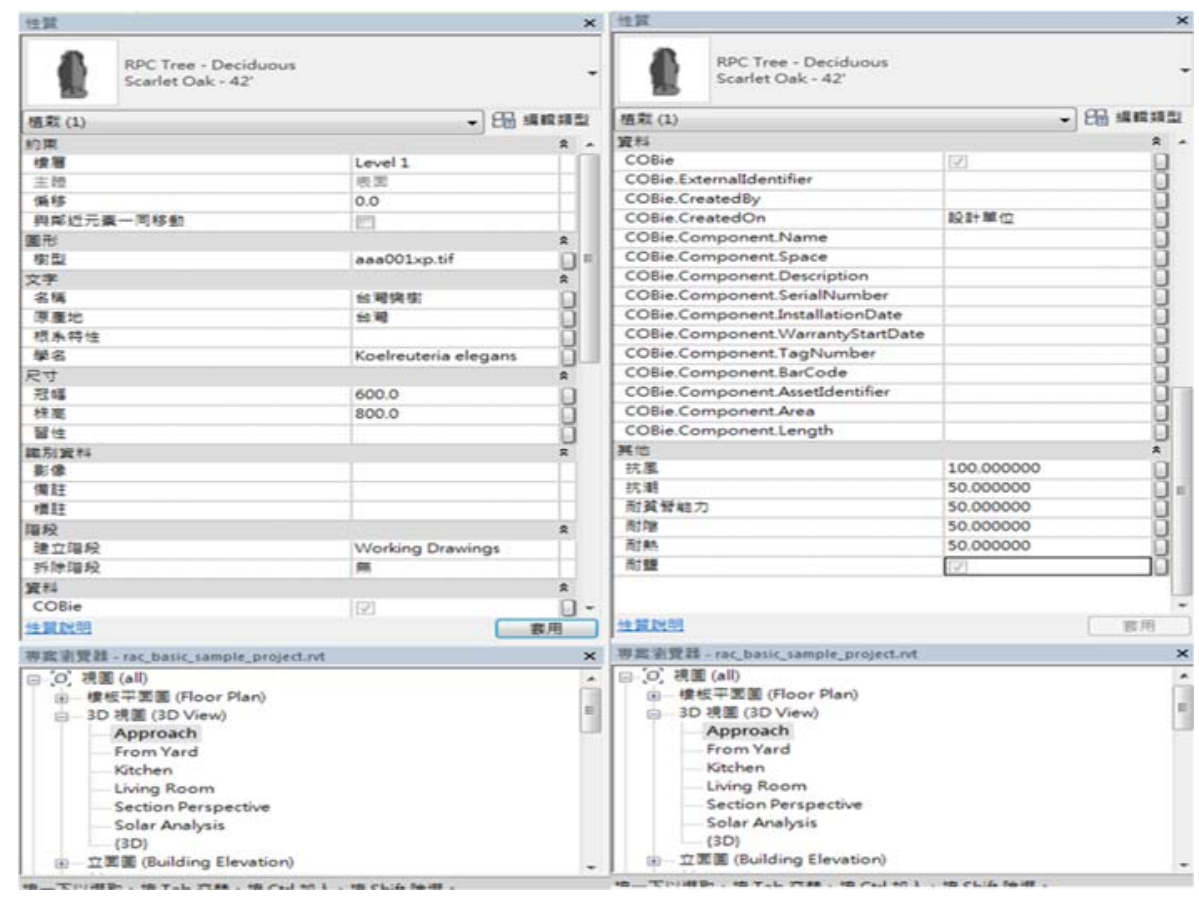

Figure 4: Schematic of attribute field expansion for BIM components of plants developed in this study. 


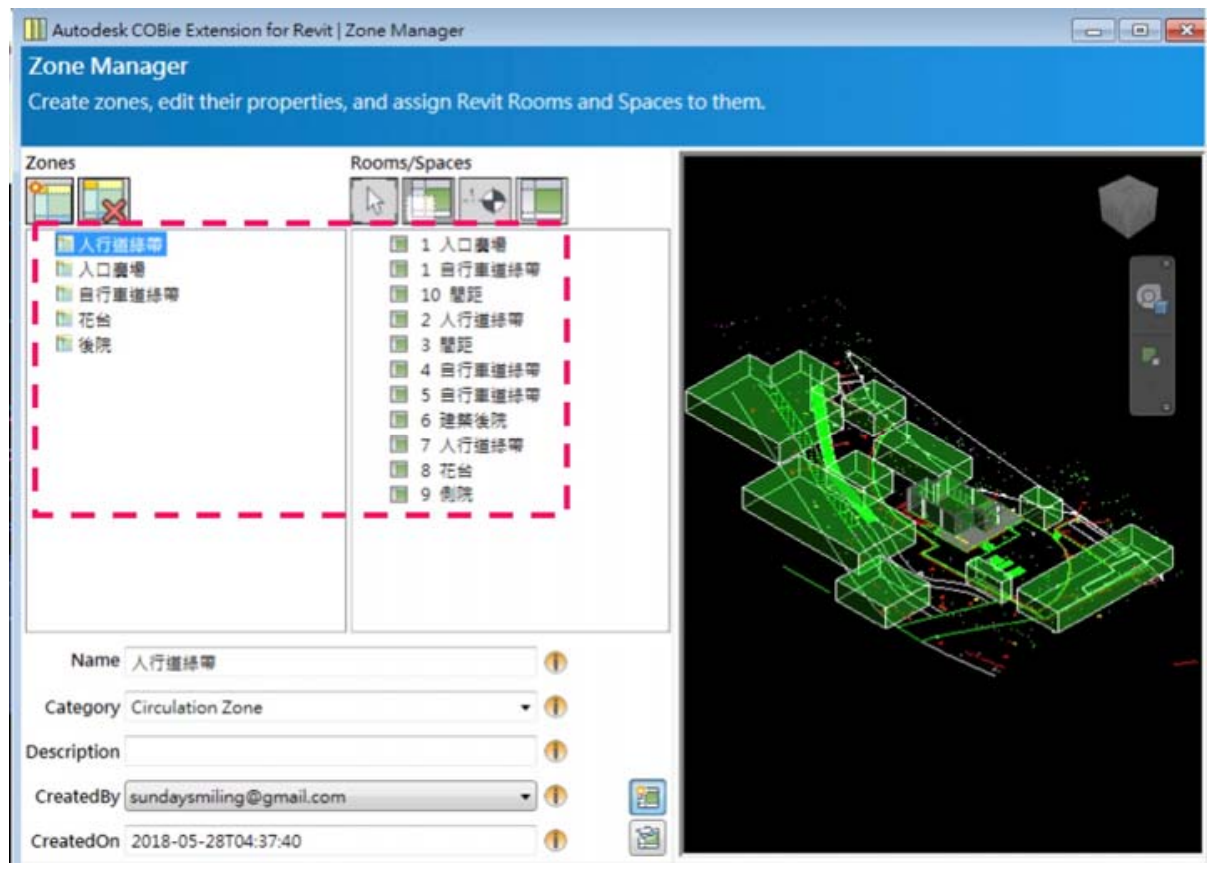

Figure 5: BIM space defined based on the maintenance and management requirement of landscape plants.

Another issue is that the way space is defined in BIM software cannot be applied to landscape planning. For example, the space is defined in Revit by forming an enclosed space through a room. Other outdoor spatial components are exported through COBie as component location information and represented by their coordinates. These approaches cannot satisfy the on-site operation requirement. Traditional on-site operation involves indicating the region and naming the location directly according to the design diagram. For example, the spatial location is called the entrance to the plaza, or region A in the flower square. Using a coordinate system makes it difficult to comprehend the information and connect the coordinates to the actual region requiring maintenance. Therefore, the spatial region is redefined in Revit in this study. In particular, outdoor plants are used to form an independent "space" that is named according to the design diagram, as shown in Fig. 5. This approach solves the issue of defining outdoor space in Revit.

\section{DEVELOPMENT OF AUGMENTED REALITY SYSTEM FOR LANDSCAPE MAINTENANCE/MANAGEMENT AND THE VALIDATION BY CASE STUDY}

A building landscape design is selected as our research object in the case study. By going through the actual simulation process of the selected case from specifications to information delivery, the system proposed in this study is validated to be suitable and feasible for forming design specifications. The base area in the case study is $5500 \mathrm{~m}^{2}$. A total of 203 arbor trees and 12,600 shrubs are included in the plants of the case study. The building information model of the selected case is shown in Fig. 6. The statistics of the plants grown in the case are summarized in Table 5. 


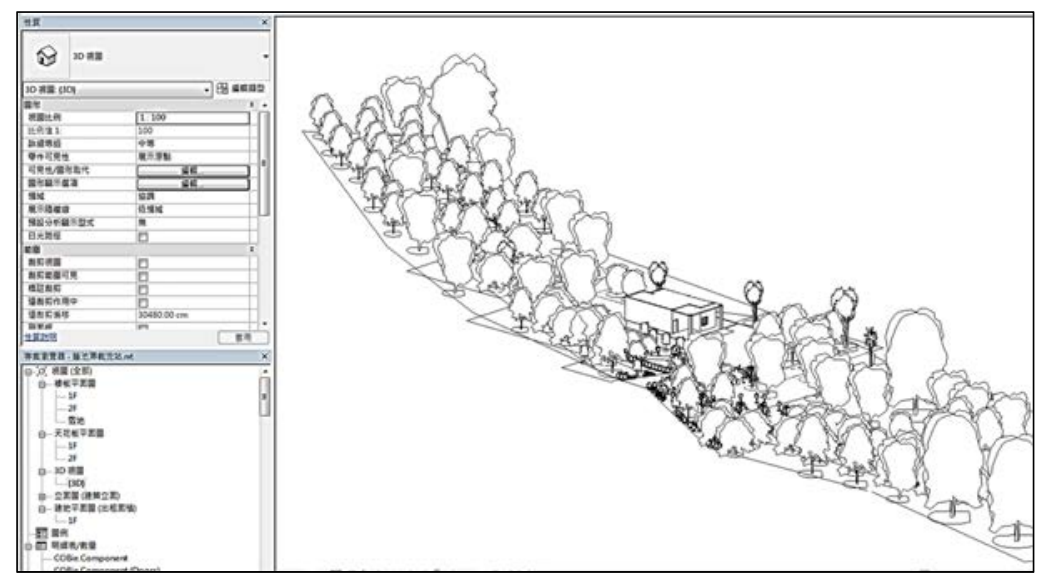

Figure 6: Building information model of the case study.

Table 5: List of the plants used in the case study.

\begin{tabular}{|c|c|c|c|c|}
\hline & Omniclass code & Plant name & Size $(\mathrm{H})$ & $\begin{array}{l}\text { Number } \\
\text { (count) }\end{array}$ \\
\hline 1 & 23.40 .05 .17 .24 & Plant_M_RPC tree - deciduous tree_terminalia $-7 \mathrm{~m}$ & 762 & 3 \\
\hline 2 & 23.40 .05 .17 .24 & Plant_M_RPC tree - deciduous tree_alstonia scholaris - $10 \mathrm{~m}$ & 960 & 6 \\
\hline 3 & 23.40 .05 .17 .24 & Plant_M_RPC tree - tropical_mid east jujube $-10 \mathrm{~m}$ & 962 & 5 \\
\hline 4 & 23.40 .05 .17 .24 & Plant_M_RPC plant - tropical_ixora flower - $1 \mathrm{~m}$ & 60 & 200 \\
\hline 5 & 23.40 .05 .17 .24 & Plant_M_RPC plant- tropical_Indian rubber $-5 \mathrm{~m}$ & 492 & 2 \\
\hline 6 & 23.40 .05 .17 .24 & Plant_M_RPC tree - autumn_eucalyptus - $10 \mathrm{~m}$ & 1000 & 10 \\
\hline 7 & 23.40 .05 .17 .24 & Plant_Taiwan Elm -12 m & 1280.6 & 8 \\
\hline 8 & 23.40 .05 .17 .24 & Plant_pongame oiltree - $4 \mathrm{~m}$ & 380 & 21 \\
\hline 9 & 23.40 .05 .17 .24 & Plant_pterocarpus indicus $-7.5 \mathrm{~m}$ & 756 & 10 \\
\hline 10 & 23.40 .05 .17 .24 & Plant_senna siamea $-8 \mathrm{~m}$ & 842 & 21 \\
\hline 11 & 23.40 .05 .17 .24 & Plant_peltophorum pterocarpum - $16 \mathrm{~m}$ & 1650 & 15 \\
\hline 12 & 23.40 .05 .17 .24 & Plant_pygmy date palm - $12 \mathrm{~m}$ & 1200 & 14 \\
\hline 13 & 23.40 .05 .17 .24 & Plant_golden trumpet tree $-6 \mathrm{~m}$ & 630 & 24 \\
\hline 14 & 23.40 .05 .17 .24 & Plant_melia azedarach $-10 \mathrm{~m}$ & 1005 & 10 \\
\hline 15 & 23.40 .05 .17 .24 & Plant_samanea saman $-15 \mathrm{~m}$ & 1542 & 12 \\
\hline 16 & 23.40 .05 .17 .24 & Plant_combretaceae - $12 \mathrm{~m}$ & 1253 & 8 \\
\hline 17 & 23.40 .05 .17 .24 & Plant_breadfruit $-6 \mathrm{~m}$ & 600 & 4 \\
\hline 18 & 23.40 .05 .17 .24 & Plant_roystonea regia $-10 \mathrm{~m}$ & 1000 & 7 \\
\hline 19 & 23.40 .05 .17 .24 & Plant_traveller's tree $-5 \mathrm{~m}$ & 500 & 15 \\
\hline 20 & 23.40 .05 .17 .24 & Plant_cassia $-8 \mathrm{~m}$ & 852 & 8 \\
\hline 21 & 23.40 .05 .17 .17 & Plant_agave $-0.7 \mathrm{~m}$ & 70 & 2640 \\
\hline 22 & 23.40 .05 .17 .17 & Plant_blackberry Lily - $0.4 \mathrm{~m}$ & 40 & 3560 \\
\hline 23 & 23.40 .05 .17 .17 & Plant_garden croton $-0.5 \mathrm{~m}$ & 50 & 2500 \\
\hline 24 & 23.40 .05 .17 .17 & Plant_kelat Paya - 0.6 m & 60 & 3200 \\
\hline 25 & 23.40 .05 .17 .17 & Plant_pink ixora $-0.4 \mathrm{~m}$ & 40 & 500 \\
\hline
\end{tabular}




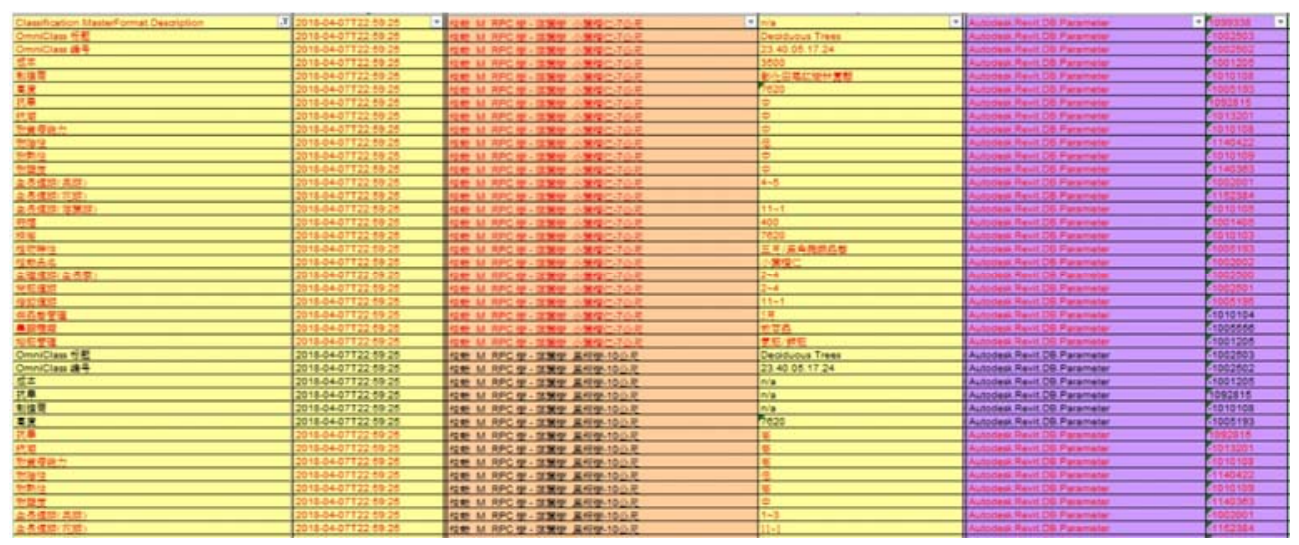

Figure 7: COBie attribute tab exported from the landscape maintenance and management building information model.

When developing the landscape maintenance and management system in this study, we first processed the information contained in the COBie form. Considering that a large amount of information is contained in the COBie form (as shown in Fig. 7) and the way such information is presented does not meet the requirement for field maintenance operations, we performed secondary data editing on the COBie form, during which the data fields are converted to a maintenance/management form satisfying the needs for field operation.

Furthermore, the integrity, mobility, and effectiveness of the information used in outdoor operations have also been considered in this study. Based on the development of the BIM-based facility maintenance and management system, an augmented reality (AR) technology is further developed and integrated into the study to ensure high integrity, mobility, and effectiveness of the information for use in landscape maintenance and management. In addition, the AR technology also allows for instantaneous visualization of the relevant information, which provides great convenience for practical maintenance work. Fig. 8 shows the architecture of the BIM-based AR landscape maintenance and management system proposed in this study. First, the BIM platform is developed using Autodesk Revit and configured using the plugin tools of Revit. In addition, the data included in the COBie form is exported using the COBie Extension. The next task is to construct AR components of the landscape plants. This is achieved by first exporting the $3 \mathrm{D}$ objects into OBJ files using OBJ Exporter, then converting these OBJ files into SCN files using Apple SceneKit, and finally integrating these $3 \mathrm{D}$ objects in a landscape maintenance iOS app using Xcode. In this study, an iOS app is developed to make it more convenient to maintain and manage landscape facilities. The app can deliver proper virtual AR elements and the associated content through a QR code. With respect to the management system for plant maintenance, a cloud-based management system is developed using JotForm to enable the manager to learn about on-site work conditions instantaneously. This system can also allow the upload of information documents and browse prior plant maintenance record files at the same time. By encoding each type of plant, the user can check the maintenance information and relevant precautions for either a single plant or a collection of plants in the entire region over different years (Fig. 9). 


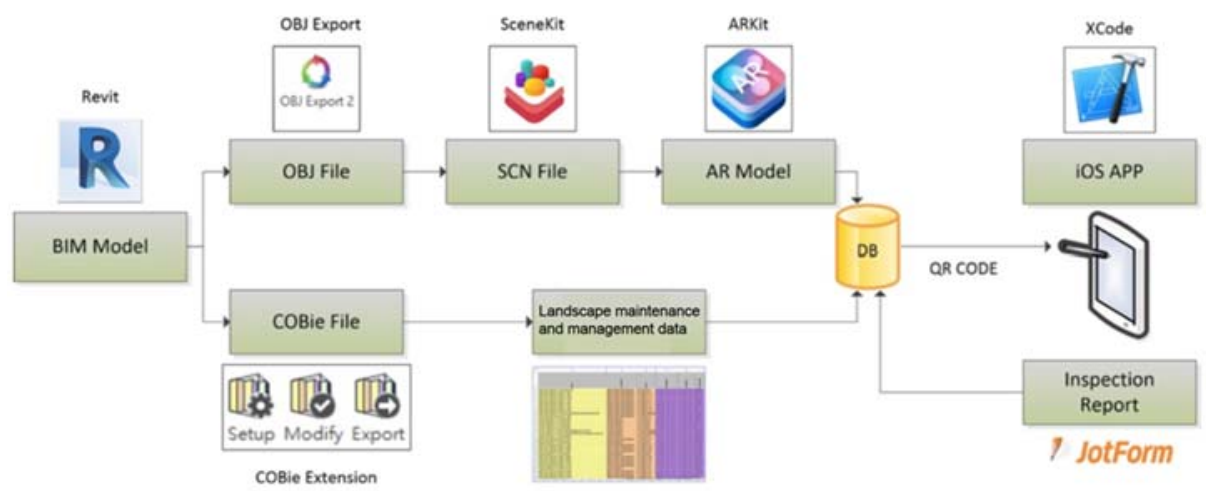

Figure 8: Architecture of BIM-based AR landscape maintenance and management system.
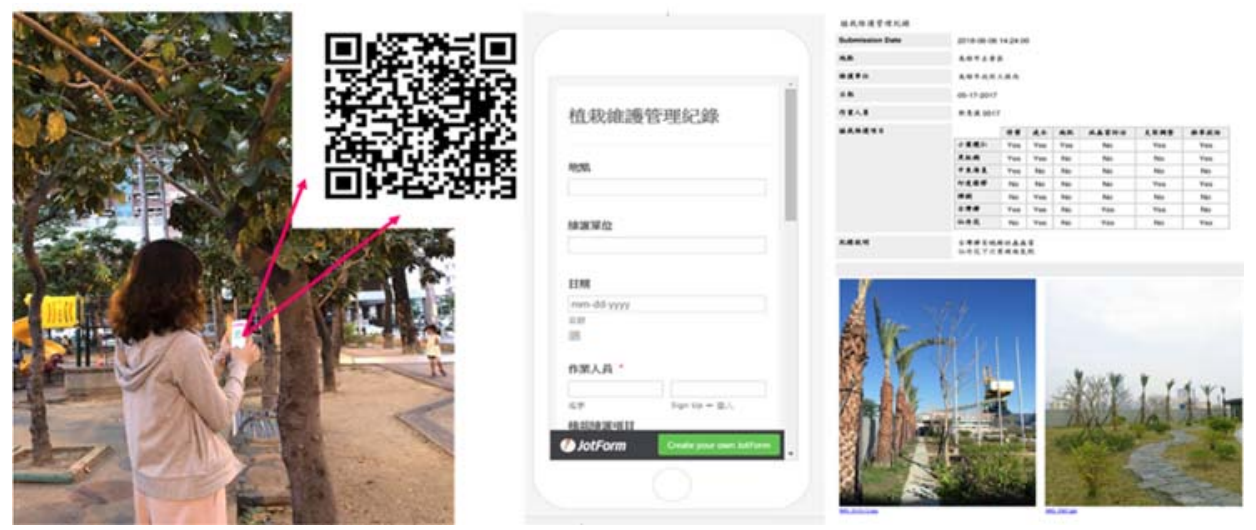

Figure 9: Application of the landscape plant maintenance and management system.

\section{CONCLUSIONS AND RECOMMENDATIONS}

This study focuses on the maintenance and management of landscape projects. In particular, we discussed the data requirement for landscape maintenance and management and developed a building information model for describing landscape maintenance information. Furthermore, we developed a BIM-based landscape maintenance and management system and validated its feasibility through a case study. The following conclusions and recommendations can be drawn from the case study: (1) the results obtained from the information requirement analysis based on the work flow of plant maintenance are suitable for use in plant maintenance and management at the back-end; (2) the specifications of delivering plant maintenance operation information can be analyzed effectively using a systematic analysis method; (3) the inspection mode and specifications of information delivery developed in this study can be expanded with the maintenance job; (4) the model developed in this study can help plan plant maintenance schedules and funding requirements in advance; (5) the quantitative data collection and analysis can also help improve and optimize the landscape plant maintenance and management system. While we have only focused on plant maintenance of landscape projects in this study, a much wider range of 
content is covered in actual landscape projects. In this study, the specifications for information delivery are developed based on the workflow of a specific task. Such a strategy can also be applied to other maintenance and management tasks in landscape projects. In future studies, the operation tasks can be expanded with an increasing number of landscape components and more relevant information to provide greater benefits in landscape maintenance and management.

\section{ACKNOWLEDGEMENT}

This work was supported by the Ministry of Science and Technology, Taiwan under Grant MOST 107-2221-E-390-009.

\section{REFERENCES}

[1] William East, E., Nisbet, N. \& Liebich, T., Facility management handover model view. Journal of Computing in Civil Engineering, 27(1), pp. 61-7, 2013.

[2] Fallon, K. \& Palmer, M.E., Capital facilities information handover guide, part 1. National Institute of Standards and Technology, 2006.

[3] Abdirad, H. \& Lin, K.-Y., Advancing in object-based landscape information modeling: Challenges and future needs. Computing in Civil Engineering, pp. 548-555, 2015.

[4] Beer, R. et al., Pharmacokinetics of intravenous linezolid in cerebrospinal fluid and plasma in neurointensive care patients with staphylococcal ventriculitis associated with external ventricular drains. Antimicrobial Agents and Chemotherapy, 51(1), pp. 379382, 2007.

[5] Zahrádková, V.A.H., Required components for Landscape Information Modelling (LIM): A literature review. Peer Reviewed Proceedings of Digital Landscape Architecture 2015 at Anhalt University of Applied Sciences, 2015.

[6] Wang, Y., Wang, X., Wang, J., Yung, P. \& Jun, G., Engagement of facilities management in design stage through BIM: Framework and a case study. Advances in Civil Engineering, pp. 1-8, 2013. 